UDC 378.147:373.011.3-051:78]:004(510)

DOI: https://doi.org/10.31470/2415-3729-2020-12-66-89

\title{
Introduction of Digital Resources in the Process of Training Musicians-Teachers in Educational Institutions of the People's Republic of China
}

\section{Iryna Dobroskok}

Doctor of Pedagogical Science (DSc), Professor,

Corresponding Member of the National Academy of

Pedagogical Sciences of Ukraine,

Head of the Professional Education Department,

Pereiaslav-Khmelnytskyi Hryhorii Skovoroda State

Pedagogical University,

$\triangle$ 30, Sukhomlynskyi Str., Pereiaslav, Kyiv Region, Ukraine, 08401

E-mail: irina.dobroskok@gmail.com

ORCID http://orcid.org/0000-0002-3937-8428

\section{Oleksii Nalyvaiko}

Doctor of Philosophy in Pedagogy (Ph.D),

Associate Professor of Pedagogy Department,

V.N. Karazin Kharkiv National University,

$\triangle 6$, Svobody Sq., Kharkiv, Ukraine, 61022

E-mail nalyvaiko@karazin.ua

ORCID: http://orcid.org/0000-0002-7094-1047

\section{Liudmyla Rybalko}

Doctor of Pedagogical Science (DSc), Professor, Head of the

Department of Pedagogics,

H.S. Skovoroda Kharkiv National Pedagogical University,

$\triangle$ 29, Alchevskykh Str, Kharkiv, Ukraine, 61002

E-mail: akme15@ukr.net

ORCID: http://orcid.org/0000-0003-1262-8551 


\section{Oksana Zhernovnykova}

Doctor of Pedagogical Science (DSc), Professor,

Head of the Department of Mathematics,

H.S. Skovoroda Kharkiv National Pedagogical University,

$\triangle 29$, Alchevskykh Str, Kharkiv, Ukraine, 61002

E-mail: oazhernovnykova@gmail.com

ORCID: http://orcid.org/0000-0002-5383-4493

Date of receipt of the article: September 28, 2020

Article accepted for publication: November 22, 2020

\section{Впровадження цифрових ресурсів у процес підготовки музикантів-педагогів у навчальних закладах КНР}

\section{Ірина Іванівна Доброскок}

доктор педагогічних наук, професор, член-кореспондент Національної академії педагогічних наук України, завідувач кафедри професійної освіти, ДВНЗ «Переяслав-Хмельницький державний педагогічний університет імені Григорія Сковороди», $\checkmark$ вул. Сковороди, 30, м. Переяслав, Київська обл., Україна, 08401

\section{Олексій Олексійович Наливайко}

кандидат педагогічних наук, доцент кафедри педагогіки, Харківський національний університет імені В. Н.

Каразіна,

$\triangle$ майдан Свободи 6, Харків, Україна,

\section{Людмила Сергіївна Рибалко}

доктор педагогічних наук, професор, професор кафедри педагогіки, 
Харківський національний педагогічний університеті імені Г. С. Сковороди,

$\checkmark$ вул. Алчевських, 29, м. Харків, Україна

\section{Оксана Анатоліївна Жерновникова}

доктор педагогічних наук, професор, завідувач кафедри математики

Харківський національний педагогічний університет імені Г. С. Сковороди, вул. Алчевських, 29, м. Харків, Україна

Дата надходження статті: 28 вересня 2020 р. Стаття прийнята до друку: 22 листопада 2020 р.

\section{Abstract}

The introduction to the article presents a theoretical analysis of the modern state of socio-economic relations development in the People's Republic of China and the role of information and digital technologies in this process. The authors considered the planned nature of the educational system based on the educational environment digitalization introduction, for example, in the plan «Modernization of Education in China by 2035» there were identified ten main strategic objectives for the modernization of education, where the main ones include: the creation of a digital educational space; using modern technology to accelerate reform of the teaching model for gifted and talented students; introducing digital formats of educational services, designing a mechanism for the joint creation of digital educational resources and exchange them; promoting changes in education, accelerating the formation of a modern system of education management and monitoring. The research purpose is to theoretically substantiate and highlight the introduction of digital resources in the process of training musicians-teachers in educational institutions of China. The main methods used in this study are the analysis and synthesis of scientific literature and open state regulatory legal acts in the field of digitalization and digital support of the 
educational process. The results and discussion provide generalized information on the introduction of digital resources in the process of musicians-pedagogues training in educational institutions of the People's Republic of China. It is noted that, according to the tasks set, in general the Chinese educational system has positively reacted to the introduction of digital teaching means in the training of future music educators. Chinese scientists have created special platforms and computer products to comprehend the art of music. The acquaintance of future musicians-teachers with digital resources of student training happens gradually and taking into account their digital literacy. The conclusions provide generalized views on the training of musicians-pedagogues in educational institutions of the People's Republic of China on the basis of the educational process digitalization.

Key words: People's Republic of China, musicianspedagogues, musical art, students, digital teaching means, digitalization.

\section{Вступ}

XXI століття $є$ часом стрімкої революції в галузі інформаційних і мережевих технологій, яка охопила весь світ. Водночас поява інноваційного покоління технологій штучного інтелекту, що характеризуються глибоким рівнем навчання, інтеграцією взаємодії людини 3 машиною, об'єктивністю й автономним контролем, стало початком нового витка технологічної революції. Усе більш актуальним стає впровадження інформаційно-цифрових технологій в освітній процес закладів освіти різних рівнів. Найбільшим ринком освітніх послуг, який сьогодні розвивається, $є$ КНР. Досягти таких значних успіхів у просвіті та навчанні свого населення КНР допомогли продумана планова політика організації освітнього процесу та широке впровадження цифрових технологій у процес підготовки майбутніх спеціалістів різних галузей соціальної сфери та 
промисловості (Ян Цзункай, 2018). Розглядаючи нормативноправове забезпечення цього процесу, не можемо не згадати мету плану «Модернізація в Китаї до 2035 року», де зазначено, що побудова сучасної соціалістичної держави до середини XXI ст. завжди була важливою частиною економічного і соціального розвитку Китаю. Починаючи 3 2000 р., інформаційно-цифрові технології поступово стають провідною рушійною силою модернізації суспільних відносин у КНР. Зокрема, у другому десятиріччі XXI століття стрімке просування інформаційно-комунікаційних технологій дало змогу значно пожвавити трансформацію китайської економіки та іiі соціальної сфери (Наливайко, 2020; Zhu, 2019).

Іншим важливим документом, який регламентує розбудову освітнього процесу на основі широкого застосування інформаційно-цифрових технологій, є план «Модернізація освіти в Китаї до 2035 року», присвячений вирішенню десяти основних стратегічних завдань 3 модернізації освіти. Так, у восьмій статті міститься заклик до прискорення реформи освіти в інформаційну епоху.

Основні заходи, спрямовані на виконання цих завдань плану, включають:

- створення цифрового освітнього простору, забезпечення необхідним обладнанням i координацію будівництва інтегрованої інтелектуальної платформи навчання;

- використання сучасних технологій для прискорення реформи моделі навчання обдарованих i талановитих здобувачів освіти й органічного поєднання масового та індивідуального стилів навчання;

- впровадження цифрових форматів освітніх послуг, розроблення механізму спільного створення й обміну цифровими освітніми ресурсами, а також удосконалення системи захисту інтелектуальної власності та нової системи нагляду за освітніми послугами; 
- сприяння змінам в управлінні освітою, прискорення формування сучасної системи управління та моніторингу освіти, а також сприяння ефективності управління i прийняття наукових рішень (Офіційний сайт Міністерства освіти КНР, 2019).

У 2015 р. Сі Цзіньпін у своєму вітальному листі на Першій міжнародній конференції з інформатизації освіти назвав важливими завданнями активне просування інтеграції інформаційних технологій, освіти та інновацій, постійне сприяння інформатизації освіти. Зазначалося також, що потрібно сприяти модернізації освіти за допомогою інформатизації освіти та прагнення до використання інформаційно-цифрових технології як засобу розширення якісної освіти за допомогою інформатизації освіти, поступове скорочення розриву в цифрових технологіях між регіонами, міськими й сільськими районами, а також активне сприяння рівності в освіті (Ду Чжаньюань, 2017).

В умовах, що склалися під впливом глобалізаційних процесів в освіті, відбуватиметься фронтальне переоцінення цінностей, учителі об'єктивно зіткнуться 3 проблемою необхідності перегляду процесу навчання, як змістовно, так i методично. Тут на передній план виходить питання об'єктивного якісного оцінювання національних дидактичних систем у ракурсі їхньої інтеграції в дидактику глобальної освітньої системи. Уже сьогодні зрозуміло, що на лідируючі позиції в цьому питанні претендують з одного боку англо-американська дидактична система, що отримала значене поширення i найбільш активно інтегрується в цифровому онлайн-просторі, а 3 іншого - китайська, яка врівноважує інноваційний потенціал англо-американської системи через залучення більшої кількості здобувачів. У таких умовах національним дидактичним системам об’єктивно доведеться підлаштовуватися під особливості і специфіку тих систем, які займуть провідні позиції, i водночас докласти великих зусиль для збереження власної ідентичності та самобутності. 
У 2018 року Міністерство освіти Китаю констатувало, що інформатизація освіти країни досягла безпрецедентно швидкого розвитку, був також реалізований проєкт «Три ланки і дві платформи». Як наслідок, потенціал застосування і рівень інформаційних технологій було значно підвищено, сприяння інформатизації істотно пожвавило реформу та розвиток освіти, було посилено міжнародний вплив китайської освітньої системи. П'ять основних цілей проєкту «Три ланки і дві платформи» було досягнуто при створенні моделі застосування освітньої інформації і забезпечення участі в цьому всього суспільства. Сприяння цьому процесу i вивчення розвитку цифровізації освіти відповідно до національних умов дали змогу досягти поставлених цілей, що заклало міцну основу для подальшого розвитку освітньої системи на засадах цифровізації. Проте як і раніше існує великий розрив між вимогами нового часу i реальною ситуацією у сфері цифровізації освіти: можливості розроблення й експлуатації цифрових освітніх ресурсів невеликі; рівень використання інформаційного навчального середовища невисокий у реальній практиці; попри доступність учителям у їхній діяльності інформаційноцифрових технологій, поширеність інноваційного навчання на основі інформації все ще є недостатньою. Інтеграція нових технологій у викладанні окремих предметів недостатньо глибока, а високоякісні дослідження та кваліфіковані вчителі, які мають необхідний рівень підготовки в галузі використання IКТ в освітньому процесі, і досі в дефіциті (Офіційний сайт міністерства освіти КНР, 2018; Чжан Вэйцзин, 2019).

Mema cmammi - теоретично обгрунтувати та висвітлити впровадження цифрових ресурсів у процес підготовки музикантів-педагогів у навчальних закладах КНР.

\section{Методи дослідження}

Серед використаних методів дослідження визначальними були такі: аналіз та узагальнення науковометодичних джерел, державних документів 3 теми 
дослідження задля теоретичного обгрунтування висвітлюваної проблеми, моделювання, синтез отриманих даних.

\section{Результати та їх обговорення}

У контексті дослідження важливо підкреслити, що до основних елементів цифровізації освіти i розбудови інфраструктури інформаційних технологій потрібно включати підготовку вчителя до використання цих технологій і сприяти прийняттю цих змін. Наприклад, уже зрозумілим стає той факт, що вчителі, школи і навіть цілі регіони не встигають адаптуватися до швидкого розвитку цифрової інфраструктури технологій i методів роботи, унаслідок чого рівень використання цифрових технологій залишається низьким (Лю Хуэйцинь, 2008). Водночас не існує всеосяжного і скоординованого механізму розвитку цифровізації шкільної освіти. Крім того, великим недоліком для освітньої цифровізації є відсутність ефективних стимулів і керівництва для інформатизації соціальної і сімейної освіти, що було доведено введенням дистанційної освіти через пандемію COVID-19.

3 проникненням інформаційних технологій в освіту i викладання створюються і широко впроваджуються цифрові освітні ресурси, такі як цифрові додатки та програми, MOOC, цифрові дидактичні ігри, віртуальне навчання тощо (Жерновникова, Перетяга, Ковтун, Кордубан, Наливайко, Наливайко, 2020; Наливайко, Резніченко, Кулакова, Кудаєва, \& Бондаренко, 2020; Nalyvaiko, Adzhva, \& Sarhsian, 2020). 3 огляду на це традиційний режим викладання, орієнтований на вчителів, навчальні матеріали та наявність класів, поступово замінюється сучасними моделями викладання, орієнтованими на учнів, впровадженням проблемного та проєктного навчання та діяльності. Розвиток цифрових навчальних ресурсів відіграє важливу роль у перетворенні освіти і викладання з традиційного на інноваційне. 
3 урахуванням тенденції розвитку міжнародних цифрових навчальних ресурсів у КНР було організовано національні курси 3 використання цифрових навчальних ресурсів (учителів та викладачів), підвищення якості цифрових освітніх матеріалів, курси обміну спеціалізованими ресурсами і відкритими заняттями. Крім того, у 2014 р. у КНР було створено Національну платформу державних освітніх ресурсів, яка включала низку курсів 3 роботи з цифровими технологіями для вчителів (Education in China, 2016).

3 огляду на всі позитивні зрушення, які вбувалися i відбуваються в системі освіти КНР, можемо виокремити низку проблем, пов'язаних із впровадженням цифрових технологій у навчальний процес. До них можна віднести дисбаланс між попитом і пропозицією цифрових освітніх ресурсів, низький рівень загального їх застосування в масштабах усього Китаю. Численні пересічні цифрові освітні ресурси не можуть повністю задовольнити реальні потреби вчителів й учнів, а долучення до якісних ресурсів, які можуть сприяти всебічному розвитку здобувача та освітнього процесу в цілому, i досі нечисленні i лише частково відповідають новому стандарту індивідуального і групового навчання учнів у КНР.

У КНР в останні двадцять років особлива увагу приділяється музичній освіті та підготовці висококваліфікованих музикантів-педагогів як запоруці всебічного розвитку членів суспільства. Підтвердженням цього процесу є збільшення контенту музичної освіти:

- поява в книжкових магазинах великої кількості підручників і літератури, присвячених музиці та музичній освіті;

- створення цифрових засобів осягнення музичного мистецтва;

- $\quad$ функціонування телевізійних каналів у галузі музики i педагогіки (центральний телеканал з музичного мистецтва, 
центральний телеканал з педагогіки, центральний телеканал з музичної педагогіки) для дітей та інших музичних програм. Зміст цих програм та їхнього освітнього контенту відрізняється дуже високим професійним рівнем і має значний рейтинг перегляду. Ці нові явища створюють сприятливу атмосферу для осягнення музики китайським народом і стимулюють інтерес до вивчення цього виду мистецтва серед усіх верств населення (Лю, 2011).

Цифрова структура загальнонаціональної системи освіти КНР набула чітких меж: школи на всіх рівнях у містах й економічно розвинених районах різною мірою створили цифрову інфраструктуру, а також отримують доступ до Інтернету; проводиться загальнодержавне встановлення цифрового обладнання в сільській місцевості; постійно збагачуються цифрові освітні ресурси в школах, триває впровадження онлайн-навчання, а цифровізація управління освітою вже досягла перших результатів. В умовах цифровізації важливе місце в системі безперервної освіти посідають дистанційно-цифрові освітні технології. Крім того, цифровізація освіти відіграла важливу роль у забезпеченні рівного доступу до освітнього контенту для багатьох верств населення (Zhu, 2019).

За словами Ц. Лю (2019), за останні 5 років кількість майданчиків для онлайн-навчання в КНР зросла 3600 тис. до понад 63 мільйонів. Як приклад впровадження в сучасний освітній процес мультимедійних технологій можна навести компанію «TAL Education Group», яка розробила систему «Магічне дзеркало»; «Baidu», що випустила систему «Розумний клас»; «GSV Capital», яка вклала кошти в платформу онлайн-навчання «Coursera» й організувала щорічний саміт «ASU GSV», присвячений освітнім технологіям.

Реформування програми підготовки вчителів музичного мистецтва в КНР спричинило використання передових технологій під час підготовки, навчання музики в 
більш відкритому і різноманітному середовищі, яке ставить за основну мету розвиток музичної творчості учнів, вимагаючи від учителів музики вищого рівня музичних здібностей, творчих методів і прийомів навчання. У старій програмі підготовки вчителів музичного мистецтва в обов'язки педагогів входило надання музичних знань i навчання учнів співу в рамках єдиної формалізованої структури навчання. Тепер реформа музичної програми принесла вчителям музики нові освітні теорії та виклики. Навантаження вчителів музики збільшилося, і тепер від них вимагається застосовувати нові підходи до навчання, щоб відповідати вимогам нової навчальної програми. Реформа музичної освіти, яка розпочалася на початку XXI століття у КНР, мала великий вплив на інноваційну підготовку вчителів музики (Feng, 2006).

Китайський вчений Лі На (2011), аналізуючи мобільність цифрового забезпечення навчального процесу, стверджує, що традиційна музична освіта, по суті, є закритим явищем, тоді як музична освіта із застосуванням цифрових технологій сприяє підвищенню професійного рівня педагогів-музикантів через більшу відкритість у спілкуванні та взаємодії з учасниками освітнього процесу. Зокрема, Лі На відзначає, що мультимедійні технології в музичній освіті не тільки розширюють канали навчання музики, але й спричиняють зміну способу мислення студентів.

За словами L. Guo (2012), основною відмінністю в підготовці майбутніх учителів музичного мистецтва за новою навчальною програмою є акцент на важливості практики i творчості в музичній освіті. Це означає, що учні не повинні отримувати музичні знання, покладаючись тільки на своїх учителів, тобто майбутньому вчителю музичного мистецтва потрібно створювати атмосферу пошуку й дослідження на свої заняттях.

X. Zhu (2006) зазначає, що зміст нової музичної програми підготовки музикантів-педагогів підкріплено чотирма основними цілями: 
- об’єднувати музичний досвід здобувачів 3 індивідуалізмом сучасної популярної культури;

- продовжувати навчання традиційних моральних цінностей;

- виховувати в здобувачів патріотичний дух;

- сприяти мультикультуралізму i визнанню світової культури.

- Просування реформи музичної освіти в КНР здебільшого залежить від актуальної практики вчителів музики, зокрема від використання інформаційно-цифрових технологій в освітньому процесі. Цінні думки щодо цього важливого питання висловив L. Guo (2012). Аналізуючи у своєму дослідженні оснащеність музичних кабінетів у китайських державних школах, він помітив таку тенденцію: окремі досвідченні вчителі не використовують сучасні цифрові технології в роботі з учнями через недостатній рівень володіння ними, що значно впливає на рівень взаємодії між учителем та учнями. Тому важливо під час підготовки майбутніх учителів музичного мистецтва приділяти значну увагу розвитку їхніх цифрових навичок у роботі 3 музичними програмами, новими гаджетами, стереоплеєрами, програмним забезпеченням для створення $\mathrm{i}$ редагування музики тощо.

Важливим елементом підготовки майбутніх учителів музичного мистецтва в КНР є створення інтерактивного цифрового супроводу у вигляді цифрових навчальнометодичних матеріалів. Китайські вчені зазначають (Чжоу Цзя, 2018; Хе Кеканг, 2012; Юй Вэнву, 2006), що різниця між поліграфічним і цифровим форматом полягає в тому, що традиційний підручник містить насамперед текстові матеріали, тоді як його цифровий аналог використовує не тільки текст, а й зображення, звук та інші супровідні матеріали. Крім того, цифрові навчально-методичні матеріали та підручники мають значно більший потенціал оперативного оновлення інформації. У зв’язку з цим у Китаї 
розрізняють три види цифрових підручників: візуальні, слухові підручники і аудіовізуальні матеріали (візуальні і слухові). Змістовне наповнення таких навчальних матеріалів включає слайди, фільми, записи, аудіозаписи.

Чжоу Цзя (2018) вважає, що цифрові навчальнометодичні матеріали поєднують у собі характеристики тексту, звуку, фільму і зображення, що забезпечує найбільш ідеальне середовище навчання і стимулює інтерес учнів до пізнання. Динамічні можливості електронної освіти, на думку Чжоу Цзя, мобілізують зорові, слухові й інші органи учнів і доводять естетичний досвід учнів у музичному сприйнятті до кульмінації, що в свою чергу є одним 3 основних завдань сучасного вчителя музичного мистецтва у KHP.

Розмірковуючи над позитивними якостями сучасної цифровізації освіти, китайський педагог Чжоу Цзя (2018) зазначає, що цифрові навчально-методичні матеріали частково замінюють функції вчителя музики для виконання будь-якого навчального завдання, наприклад, для надання навчальної інформації; роблять навчання в класі динамічним на противагу статичному традиційному; розширюють інформаційний потенціал і дають змогу отримувати більш широкий спектр знань щодо музичного мистецтва.

Чень Цун (2013) вважає, що цифрова освіта є одним із символів модернізації освіти, найбільш ефективним засобом підвищення ефективності навчання і серйозної реформи методів навчання в музичній сфері. За словами Чень Цун, під час застосування вчителем цифрових технологій слід враховувати характеристику аудіовізуальних засобів навчання, рівень здібностей учнів і розвивальний потенціал підручників, у тому числі цифрових. Наприклад, у підручнику здобувач познайомиться з нотним текстом пісні, а за допомогою цифрових засобів навчання дізнається про композитора й автора тексту, історію створення пісні та багато чого іншого. Зокрема, якщо раніше процес знайомства 
3 національними інструментами був ускладнений їхнім придбанням, зберіганням та обслуговуванням, то зараз за допомогою мультимедійних засобів учитель може не лише продемонструвати ілюстрації в підручниках, а й показати способи гри, надати можливість почути тембри музичних інструментів, що значно підвищує зацікавленість здобувачів у процесі навчання (Чень Цун, 2013).

У контексті питання, яке розглядається, важливо зазначити, що цифрові засоби навчання відкривають значні можливості в осягненні музичного мистецтва здобувачами освіти, проте не потрібно забувати, що цифрові засоби навчання повинні виступати як допоміжний інструментарій підготовки здобувачів, а не заміняти педагога. Ця думка підтверджується дослідженнями Чжан Цзюня, де вчений наполягає на тому, що цифровізація музичної освіти допомагає подолати обмеження часу, простору і регіону; сприяти синестезії почуттів; стимулювати навчальну мотивацію й інтерес учнів; прискорювати навчальний зв'язок з учнями; швидкість сприйняття інформації, але все це можливо лише за високої професійної майстерності педагога-музиканта та його цифрової обізнаності (Чжан Цзюнь, 2012).

Інтеграція комп'ютерних технологій у навчальну діяльність стала новим трендом сучасного навчання. Завдяки впровадженню комп'ютерного музичного навчання вчитель може комбінувати текстові матеріали, зображення, анімацію, аудіо та відео на комп'ютері, щоб надати студентам різноманітний досвід навчання. Як наслідок, САМІ (Computer-Assisted Musical Instruction) може відкрити нові можливості у викладанні і кардинально змінити способи вивчення музики. Колектив китайських вчених (Lou, Guo, Zhu, Shih \& Dzan, 2011). розробив набір навчального програмного забезпечення, яке полегшило вчителю музики викладання курсу вивчення китайських музичних інструментів за допомогою цифрового програмного забезпечення. 
Підготовка майбутніх учителів музичного мистецтва за допомогою САМІ поєднує комп’ютери та музичні інструкції, щоб забезпечити сприятливе середовище для навчання та досягнення заздалегідь установлених цілей навчання. Цей підхід можна використовувати для вивчення музичної композиції, корегування отриманих музичних навичок, оцінювання музичних творів та споглядання гри на музичних інструментах. Китайська розробка в галузі підготовки здобувачів освіти до роботи 3 традиційними народними інструментами CAMI Software включає шість блоків, короткий вступ до китайських народних музичних інструментів, класифікаційні схеми китайських музичних інструментів, духових, струнних, псалтирних й ударних інструментів (Lou, Guo, Zhu, Shih \& Dzan, 2011).

Функціонал оцінювання в CAMI складається за таким алгоритмом: після відпрацювання кожного музичного інструмента сторінка оцінювання може допомогти викладачам зрозуміти, наскільки студенти розуміють китайські музичні інструменти, чи повністю розуміє здобувач класифікацію музичних інструментів та над чим потрібно більше працювати.

\section{Висновки}

Аналіз науково-педагогічної літератури та нормативноправового забезпечення функціонування освітньої системи КНР допомогло зрозуміти, що сучасний стан підготовки майбутніх педагогів-музикантів 3 використанням цифрових засобів навчання включає такі фактори:

- плановість підготовки майбутніх фахівців: через зростання попиту на культурний розвиток підростаючого покоління корегується кількість педагогів-музикантів;

- чіткість i розуміння важливості впровадження цифрових технологій у навчальний процес на всіх рівнях освіти;

- розвиток цифрової грамотності й обізнаності майбутніх учителів музики на сучасних технологіях та підходах до їх імплементації в навчанні музичного мистецтва; 
- перегляд освітніх програм і стандартів підготовки майбутніх учителів музичного мистецтва на засадах цифровізації суспільного життя;

- допомога в осягненні цифрових технологій незалежно від соціального стану й економічного розвитку для регіонів, тобто зменшення «цифрового розриву» між заможними містами та сільською місцевістю;

- акцент на національних цифрових освітніх продуктах та їхня підтримка в навчальній діяльності учасників освітнього процесу.

У подальших наукових дослідженнях планується більш детально дослідити освітні стандарти підготовки вчителів музичного мистецтва відповідно до плану «Модернізація освіти в Китаї до 2035 року».

\section{Література}

1. Ду Чжаньюань. Сприяння модернізації освіти за допомогою інформатизації освіти. URL : http:/www.moe.gov.cn/s78/A16/s5886/s7986/201710/t20171023 _317111.html (дата звернення: 10.09.2020) (кит).

2. Жерновникова О., Перетяга Л., Ковтун А., Кордубан М., Наливайко О., Наливайко Н. Технологія формування цифрової компетентності майбутніх учителів засобами гейміфікації. Інформаційні технологї $i$ засоби навчання. 2020. 75 (1). 170-185.

3. Лі На. Теорія музичного електронної освіти. Масове мистецтво і література. 2011. 11. С. 195.

4. Лю Хуейцінь. Три неминучі проблеми в швидкому розвитку інформатизації освіти. Інформаційні технології освіти. Початкова і середня школа. 2008. № 10. С. 80-81 (кит).

5. Лю Лянь. Влияние системы музыкального образования бывших стран СССР на развитие современной музыкальной педагогики Китая. Проблеми взаємодіi мистецтвва, педагогіки та теорії і практики освіти. 2011. (33). 266-274. 
6. Лю Цюнь. Анализ внедрения в профессиональную подготовку педагога-музыканта

электронных образовательных ресурсов как мультимедийного сопровождения учебного процесса. Перспективы науки. 2019. (4). 124-134

7. Мэй Хонг. Створення цифрового Китаю: використання можливості нового етапу розвитку інформатизації. People's. Жэньминь жибао. 2018. Вип. 05 (кит.).

8. Наливайко О. Цифровізація освітнього середовища в закладах вищої освіти китайської народної республіки. Актуальні питання гуманітарних наук. 2020. 2(32). 188-194.

9. Наливайко О., Резніченко Г., Кулакова I., Кудаєва О., Бондаренко А. Вивчення китайської мови за допомогою цифрових додатків. Наукові записки кафедри педагогіки. 2020. 47. 64-77. https://doi.org/10.26565/2074-8167-2020-47-08

10. Офіційний сайт Міністерства освіти КНР (2019). План «Модернізація освіти до 2035 р.». URL : http:/www.moe.gov.cn/jyb_xwfb/s6052/moe_838/201902/. (дата звернення: 10.09.2020) (кит.).

11. Офіційний сайт міністерства освіти КНР (2018). План дій щодо інформатизації освіти 2.0. URL : http://www.moe.gov.cn/srcsite/A16/s3342/201804/t20180425_33 4188.html. (дата звернення: 10.09.2020) (кит).

12. Хе Кеканг. Вивчення «Десятиліття розвитку інформатизації освіти». Інтерпретація «Поглиблена інтеграція інформаційних технологій і освіти». Дослідження в області електрохімічного освіти. 2012. № 12. С. 19-23 (кит.).

13. Чень Цун. Дослідження i практика музичного мультимедійного електронного освіти. Голос Жовтої ріки. 2013. № 13. С. 70 (кит.).

14. Чжан Вэйцзин (2019). Інформатизація освіти в Китаї різко змінилася за 70 років. URL : https://news.eol.cn/ 
uni/201909/t20190926_1684908.shtml (дата звернення: 10.09.2020) (кит.).

15. Чжан Цзюнь. Електронна освіта у музичному вихованні дітей. Північна музика. 2012. № 12. С. 90. (кит.).

16. Юй Венву, Цзясин Се. Музична освіта та методика навчання: підручник. Пекін: Вища освіта, 2006. 238 с. (кит.).

17. Ян Цзункай. Інформатизація базової освіти 2.0: шлях науки і техніки Китаю, що сприяє інноваціям і розвитку в освіті. Цифрове навчання в початкових і середніх школах. 2018. № 4. С. 23-25 (кит.).

18. Education in China: Snapshot. Secretary-General of the OECD. 2016. 64 p. URL : https:/www.oecd.org/ education/ Education-in-China-a-snapshot.pdf (дата звернення: 10.09.2020).

19. Feng D.. China's recent curriculum reform: Progress and problems. Planning and Changing. 2006. 37. 131-144.

20. Guo L. New curriculum reform in china and its impact on teachers. Canadian and International Education/Education Canadienne et internationale. 2012.41(2). 6.

21. Lou S. J., Guo Y. C., Zhu Y. Z., Shih R. C., \& Dzan W. Y.. Applying computer-assisted musical instruction to music appreciation course: An example with Chinese musical instruments. Turkish Online Journal of Educational TechnologyTOJET. 2011. 10(1). 45-57.

22. Nalyvaiko O., Adzhva D., \& Sarhsian E. Distance Education in V.N. Karazin Kharkiv National University in 2030, Students' View. Electronic Scientific Professional Journal «Open Educational E-Environment of Modern University». 2020. (9). 79-94. https://doi.org/10.28925/2414-0325.2020.9.7

23. Zhu X. Moral education and values education in curriculum reform in China. Frontiers of Education in China: Selected Publications from Chinese Universities. 2006. 1(2). 191-200. DOI:10.1007/s11516-006-0002-7

24. Zhu Y. New National Initiatives of Modernizing Education in China. ECNU Review of Education. 2019. 2(3). 353-362. 


\section{References}

1. Du, Zhanyuan (2017). Spryiannia modernizatsii osvity za dopomohoiu informatyzatsii osvity [Promoting the modernization of education through the informatization of education]. Retrieved from http:/www.moe.gov.cn/s78/ A16/s5886/s7986/201710/ t20171023_317111.html [in Chinese].

2. Zhernovnykova, O., Peretiaha, L., Kovtun, A., Korduban, M., Nalyvaiko, O., \& Nalyvaiko, N. (2020). Tekhnolohiia formuvannia tsyfrovoi kompetentnosti maibutnikh uchyteliv zasobamy heimifikatsii [The technology of prospective teachers' digital competence formation by means of gamification]. Information Technologies and Learning Tools, 75(1), 170-185. https://doi.org/10.33407/itlt.v75i1.3036 [in Ukrainian].

3. Lee, $\mathrm{Na}$ (2011). Teoriia muzychnoho elektronnoi osvity. Masove mystetstvo i literatura [Theory of music e-education]. Mass art and literature, 11, 195 [in Chinese].

4. Liu, Huiqin (2008). Try nemynuchi problemy v shvydkomu rozvytku informatyzatsii osvity [Three inevitable problems in the rapid development of informatization of education]. Information technologies of education. Primary and secondary school, 10, 80-81 [in Chinese].

5. Liu, Lian (2011). Vliyanie sistemy` muzy`kal’nogo obrazovaniya by`vshikh stran SSSR na razvitie sovremennoj muzy`kal'noj pedagogiki Kitaya [The influence of the music education system of the former USSR countries on the development of modern music pedagogy in China]. Problems of interaction of art, pedagogy and theory and practice of education, (33), 266-274 [in Russian].

6. Liu, Qun (2019). Analiz vnedreniya v professional'nuyu podgotovku pedagoga-muzy`kanta obrazovatel'ny`kh resursov kak mul'timedijnogo soprovozhdeniya uchebnogo proczessa [Analysis of the introduction of electronic educational resources into the professional training of a music teacher as a multimedia support for the educational process]. Science perspectives, (4), 124-134 [in Russian]. 
7. Mei, Hong (2018). Stvorennia tsyfrovoho Kytaiu: vykorystannia mozhlyvosti novoho etapu rozvytku informatyzatsii [Creation of digital China: seizing the possibility of a new stage in the development of informatization]. People's. People's Daily. Issue. 05 [in Chinese].

8. Nalyvaiko, O. (2020). Tsyfrovizatsiia osvitnoho seredovyshcha $\mathrm{v}$ zakladakh vyshchoi osvity kytaiskoi narodnoi respubliky [Digitization of the educational environment in higher education institutions of the People's Republic of China]. Current issues of the humanities, 2 (32), 188-194 [in Ukrainian].

9. Nalyvaiko, O., Reznichenko, H, Kulakova, I., Kudaieva O., \& Bondarenko, A. (2020). Vyvchennia Kytaiskoi movy za dopomohoiu tsyfrovykh dodatkiv [Learning Chinese using digital applications]. Scientific Notes of the Pedagogical Department, 1(47), 64-77. https://doi.org/10.26565/2074-8167-2020-47-08 [in English].

10. Official website of the Ministry of Education of the People's Republic of China (2019). Plan «Modernizatsiia osvity do 2035 r.» [Plan «Modernization of education until 2035»]. Retrieved from http://www.moe.gov.cn/jyb_xwfb/ s6052/moe_838/201902/ [in Chinese].

11. Official website of the Ministry of Education of the People's Republic of China (2018). Plan dii shchodo informatyzatsii osvity 2.0. [Education Informatization Action Plan 2.0.]. Retrieved from http://www.moe.gov.cn/srcsite/ A16/s3342/201804/t20180425_334188.html [in Chinese].

12. He, Kekang (2012). Vyvchennia «Desiatylittia rozvytku informatyzatsii osvity». Interpretatsiia «Pohlyblena intehratsiia informatsiinykh tekhnolohii i osvity» [Study of the «Decade of Development of Education Informatization». Interpretation «Indepth integration of information technology and education»]. Research in the field of electrochemical education, 12, 19-23 [in Chinese].

13. Chen, Tsun (2013). Doslidzhennia i praktyka muzychnoho multymediinoho elektronnoho osvity [Research and practice of music multimedia e-education]. The voice of the Yellow River, 13, 70 [in Chinese]. 
14. Zhang, Weijing (2019). Informatyzatsiia osvity v Kytai rizko zminylasia za 70 rokiv [The informatization of education in China has changed dramatically in 70 years]. Retrieved from https://news.eol.cn/uni/201909/t20190926_1684908.shtml [in Chinese].

15. Zhang, Jun (2012). Elektronna osvita u muzychnomu vykhovanni ditei [E-learning in children's music education]. Northern music, 12, 90 [in Chinese].

16. Yu, Wenwu, Jiaxing, Xie (2006). Muzychna osvita ta metodyka navchannia: pidruchnyk. [Music education and teaching methods: a textbook]. Beijing: Higher Education, 238 p. [in Chinese].

17. Yang, Tsunkai (2018). Informatyzatsiia bazovoi osvity 2.0: shliakh nauky i tekhniky Kytaiu, shcho spryiaie innovatsiiam i rozvytku v osviti [Informatization of Basic Education 2.0: China's Science and Technology Pathway Promoting Innovation and Development in Education]. Digital education in primary and secondary schools, 4, 23-25 [in Chinese].

18. Education in China: Snapshot. Secretary-General of the OECD. 2016. 64 p. Retrieved from https://www.oecd.org/ education/Education-in-China-a-snapshot.pdf [in English].

19. Feng, D. (2006). China's recent curriculum reform: Progress and problems. Planning and Changing, 37, 131-144 [in English].

20. Guo, L. (2012). New curriculum reform in china and its impact on teachers. Canadian and International Education/Education Canadienne et internationale, 41(2), 6 [in English].

21. Lou, S.J., Guo, Y.C., Zhu, Y.Z., Shih, R.C., \& Dzan, W.Y. (2011). Applying computer-assisted musical instruction to music appreciation course: An example with Chinese musical instruments. Turkish Online Journal of Educational TechnologyTOJET, 10(1), 45-57 [in English].

22. Nalyvaiko, O., Adzhva, D., \& Sarhsian, E. (2020). Distance Education in V.N. Karazin Kharkiv National University in 2030, Students' View. Electronic Scientific Professional 
Journal «Open Educational E-Environment of Modern University», (9), 79-94. https://doi.org/10.28925/24140325.2020.9.7 [in English].

23. Zhu, X. (2006). Moral education and values education in curriculum reform in China. Frontiers of Education in China: Selected Publications from Chinese Universities, 1(2), 191-200. doi:10.1007/s11516-006-0002-7 [in English].

24. Zhu, Y. (2019). New National Initiatives of Modernizing Education in China. ECNU Review of Education, 2(3), 353-362 [in English].

\section{Доброскок І. І., Наливайко О. О., Рыбалко Л. С., Жерновникова О. А.}

\section{Впровадження цифрових ресурсів у процес підготовки музикантів-педагогів у навчальних закладах КНР}

\section{Анотація}

У вступі статті представлено теоретичний аналіз сучасного стану розвитку соціально-економічних відносин у Китайській Народній Республіці та роль інформаційноцифрових технологій у цьому процесі. Розглянуто плановий характер розбудови освітньої системи на засадах впровадження цифровізації освітнього середовища, наприклад, у плані «Модернізація освіти в Китаї до 2035 року», визначено десять основних стратегічних завдань 3 модернізації освіти. До основних $з$ них віднесено: створення цифрового освітнього простору; використання сучасних технологій для прискорення реформи моделі навчання обдарованих і талановитих здобувачів освіти; впровадження цифрових форматів освітніх послуг, розроблення механізму спільного створення цифрових освітніх ресурсів й обміну ними; сприяння змінам в управлінні освітою, прискорення формування сучасної системи управління та моніторингу освіти. Основними методами, які використовувалися в 
даному дослідженні, є аналіз і синтез наукової літератури й відкритих державних нормативно-правових актів у галузі цифровізації та цифрового супроводу освітнього процесу. У результатах та обговоренні наведено узагальнені відомості про впровадження цифрових ресурсів у процес підготовки музикантів-педагогів у навчальних закладах Китайської Народної Республіки. Зазначено, що, згідно з поставленими завданнями, в основному китайська освітня система позитивно сприйняла впровадження цифрових засобів навчання в процес підготовки майбутніх учителів музичного мистецтва. Китайськими вченими було створено спеціальні платформи та комп'ютерні продукти для осягнення музичного мистецтва. Знайомство майбутніх музикантівпедагогів із цифровими ресурсами підготовки здобувачів відбувається поступово та з урахуванням їхньої цифрової грамотності. У висновках представлено узагальнені положення щодо підготовки музикантів-педагогів у навчальних закладах Китайської Народної Республіки на засадах цифровізації освітнього процесу.

Ключові слова: КНР, музиканти-педагоги, музичне мистецтво, студенти, цифрові засоби навчання, цифровізація.

\section{Доброскок И. И., Наливайко А. А., Рыбалко Л. С., Жерновникова О. А.}

\section{Внедрение цифровых ресурсов в процесс подготовки музыкантов-педагогов в учебных заведениях КНР}

\section{Аннотация}

Во введении к статье представлен теоретический анализ современного состояния развития социальноэкономических отношений в Китайской Народной Республике и роль информационно-цифровых технологий в этом процессе. Рассмотрен плановый характер развития образовательной системы на основе внедрения 
цифровизации образовательной среды, например, в плане «Модернизация образования в Китае к 2035 году», определены десять основных стратегических задач по модернизации образования. К основным из них отнесены: создание цифрового образовательного пространства; использование современных технологий для ускорения реформы модели обучения одаренных и талантливых учащихся; внедрение цифровых форматов образовательных услуг, разработка механизма совместного создания цифровых образовательных ресурсов и обмена ними; содействие изменениям в управлении образованием, ускорению формирования современной системы управления и мониторинга образования. Основные методы, которые использовались в данном исследовании, - это анализ и синтез научной литературы и открытых государственных нормативно-правовых актов в области цифровизации и цифрового сопровождения образовательного процесса. В результатах и обсуждении представлены обобщенные сведения по внедрению цифровых ресурсов в процесс подготовки музыкантов-педагогов в учебных заведениях Китайской Народной Республики. Отмечено, что согласно поставленным задачам в основном китайская образовательная система положительно восприняла внедрение цифровых средств обучения в процесс подготовки будущих учителей музыкального искусства. Китайскими учеными были созданы специальные платформы и компьютерные продукты для постижения музыкального искусства. Знакомство будущих музыкантов-педагогов с цифровыми ресурсами подготовки учащихся происходит постепенно и с учетом их цифровой грамотности. В выводах представлены обобщенные положения по подготовке музыкантов-педагогов в учебных заведениях Китайской Народной Республики на основе цифровизации образовательного процесса.

Ключевые слова: КНР, музыканты-педагоги, музыкальное искусство, студенты, цифровые средства обучения, цифровизация. 